\title{
Erratum to: Working memory training in children: Effectiveness depends on temperament
}

\author{
Barbara Studer-Luethi $^{1,2}$ • Catherine Bauer ${ }^{3}$ - Walter J. Perrig ${ }^{1,2}$
}

(C) Psychonomic Society, Inc. 2016

\section{Erratum to: Mem Cogn}

DOI: $10.3758 / \mathbf{s} 13421-015-0548-9$

Note that the captions provided for Figs. 3 and 4 in this article were reversed-i.e., the caption for Fig. 4 was placed with Fig. 3 and the caption for Fig. 3 was placed with Fig. 4.

The online version of the original article can be found at http://dx.doi.org/ 10.3758/s13421-015-0548-9.

\footnotetext{
Barbara Studer-Luethi

barbara.studer@psy.unibe.ch
}

1 Department of Psychology, University of Bern, Fabrikstrasse 8, CH 3012 Bern, Switzerland

2 Center for Cognition, Learning, and Memory, University of Bern, Bern, Switzerland

3 School for Teacher Education, Bern, Switzerland 